\title{
Isolation, characterization and differentiation of mesenchymal stem cells from amniotic fluid, umbilical cord blood and Wharton's jelly in the horse
}

\author{
Eleonora lacono, Lara Brunori, Alessandro Pirrone, Pasquale Paolo Pagliaro ${ }^{1}$, Francesca Ricci ${ }^{1}$, \\ Pier Luigi Tazzari ${ }^{1}$ and Barbara Merlo \\ Department of Veterinary Medical Sciences, University of Bologna, via Tolara di Sopra 50, 40064 Ozzano Emilia, \\ Bologna, Italy and ${ }^{1}$ Immunohaematology and Transfusion Center, Policlinico S.Orsola-Malpighi, Bologna, Italy
}

Correspondence should be addressed to E lacono; Email: eleonora.iacono2@unibo.it

\begin{abstract}
Mesenchymal stem cells (MSCs) have been derived from multiple sources of the horse including umbilical cord blood (UCB) and amnion. This work aimed to identify and characterize stem cells from equine amniotic fluid (AF), CB and Wharton's Jelly (WJ). Samples were obtained from 13 mares at labour. AF and CB cells were isolated by centrifugation, while WJ was prepared by incubating with an enzymatic solution for $\mathbf{2} \mathbf{h}$. All cell lines were cultured in DMEM/TCM199 plus fetal bovine serum. Fibroblast-like cells were observed in $7 / 10(70 \%)$ AF, 6/8 (75\%) CB and 8/12 (66.7\%) WJ samples. Statistically significant differences were found between cell-doubling times (DTs): cells isolated from WJ expanded more rapidly ( $2.0 \pm 0.6$ days) than those isolated from CB (2.6 \pm 1.3 days) and AF (2.3 \pm 1.0 days) $(\boldsymbol{P}<\mathbf{0 . 0 5})$. Positive von Kossa and Alizarin Red S staining confirmed osteogenesis. Alcian Blue staining of matrix glycosaminoglycans illustrated chondrogenesis and positive Oil Red $O$ lipid droplets staining suggested adipogenesis. All cell lines isolated were positive for CD90, CD44, CD105; and negative for CD34, CD14 and CD45. These findings suggest that equine MSCs from AF, UCB and WJ appeared to be a readily obtainable and highly proliferative cell lines from a uninvasive source that may represent a good model system for stem cell biology and cellular therapy applications in horses. However, to assess their use as an allogenic cell source, further studies are needed for evaluating the expression of markers related to cell immunogenicity.
\end{abstract}

Reproduction (2012) 143 455-468

\section{Introduction}

Over the past decade, stem cell research has emerged as an area of major interest due to its potential in regenerative medicine applications (Stocum 2001). The three alternative stem cells are embryonic stem cells (ESCs), adult stem cells (ASCs) and induced pluripotent stem (IPS) cells.

ESCs are derived from blastocysts that propagate readily (Thomson et al. 1998) and are capable of forming embryoid bodies that generate a variety of specialized cells including neural, cardiac and pancreatic cells (Reubinoff et al. 2000). The establishment of horse ESC lines is of interest for creation of models of human genetic diseases and cell transplantation therapies. Horse ESC lines would also be useful in the genetic engineering of these animals for improved production traits and products for disease resistance and biopharming. However, horses have the disadvantages of low embryo numbers harvested during in vivo blastocysts collection or in vitro embryo production (HacKett \& Fortier 2011). Saito et al. (2002) isolated for the first time
ES-like cells from equine blastocysts and induced their in vitro differentiation. In human, different authors observed that after ESCs in vivo implantation teratomas have been developed. Li et al. (2006) injected equine ES-like cells into several combined immune deficient mice and observed no teratoma formation. However, tumour formation by stem cells is more common when they are injected into the same species from which they were derived (Erdo et al. 2003). Recently, the injection of undifferentiated equine ES-like cells into experimentally induced tendon lesions has been reported by Guest et al. (2010). In the study, at no time was there any evidence of teratoma formation by the horse ESCs, or differentiation into unwanted cell types; however, longer follow-up periods in larger numbers of horses are required to demonstrate full safety.

Accordingly, many scientists have focused on alternative sources of stem cells from various mesenchymal tissues, such as bone marrow mesenchymal stem cells (BMMSCs; Horwitz et al. 1999), adipose tissue (Seo et al. 2005) and umbilical cord (UC; Romanov et al. 2003). MSCs have distinct cell-surface antigen markers. 
As reported by the International Society of Cellular Therapy, MSC populations express CD73, CD90 and CD105. CD73 is a purine catabolic enzyme with broad substrate specificity that catalyses the dephosphorylation of purine and pyrimidine ribo- and deoxyribonucleoside monophosphates to their corresponding nucleosides (Naito \& Lowenstein 1981); furthermore, CD73 has been postulated to play a role in cell adhesion (Airas et al. 1995). CD90, also called Thy-1, is originally discovered as a thymocyte antigen. Thy- 1 can be used as a marker for a variety of stem cells and for the axonal processes of mature neurons, even if its function has not yet been fully elucidated: it has speculated its roles in cell-cell and cell-matrix interactions, with implication in neurite outgrowth, nerve regeneration, apoptosis, metastasis, inflammation and fibrosis (Nakamura et al. 2006). CD105, or endoglobin, is a well-known MSC marker: it is a part of TGF $\beta$ receptor complex. It thus may be involved in the binding of TGF $\beta 1,3$, etc. but it is also involved in cytoskeletal organization affecting cell morphology and migration (Dominici et al. 2006). Additionally, MSCs lack expression of haematopoietic markers, such as CD14, CD34 and CD45. CD45 is a pan-leukocyte marker; CD34 markers are primitive haematopoietic progenitors and endothelial cells; and CD14 is prominently expressed in monocytes and macrophages (Dominici et al. 2006).

The difficulties with bone marrow are obtaining tissue samples from donors and finding a significant decrease in both quality and differentiation potential of BMMSCs with age donor. Widely disparate results have been reported with regard to MSC numbers, differentiation potency and aging. A negative correlation between donor age, number and proliferative capacity of MSCs isolated from young and old donors has been demonstrated by several authors (Martin et al. 1970, Schneider \& Mitsui 1976, Majors et al. 1997, D'lppolito et al. 1999, Stenderup et al. 2003, Mareschi et al. 2006), but widely different results have been obtained with regard to MSC antigen expression. Recently, Stolzing et al. (2008) confirmed those already demonstrated in previous studies (D'Ippolito et al. 1999, Mendes et al. 2002, Chen et al. 2005, Zhang et al. 2005, Zheng et al. 2007, Kretlow et al. 2008), observing a significant age-related change in membrane markers expression levels, an alkaline phosphatase activity, chondrogenic and myogenic differentiation potency decline with donor age in contrast with adipogenic differentiation. However, these data are in contrast with those reported by other research groups (Bergman et al. 1996, Stenderup et al. 2001, 2003, Bellows et al. 2003), which showed no age-related differences in differentiation potency. Different results obtained are with regard to the choice of age groups, group size, gender, inclusion of pathological states, isolation and cultivation conditions (Sethe et al. 2006). In equine medicine, only Colleoni et al. (2009) reported a significant decline in the yield of cells from samples of two old horses (8 and 9 years old); however, due to the low number of samples examined in this study, data need to be further confirmed.

Beyond natural sources that are limited by stem cell availability, immune intolerance and lineage specification, the latest platform for recently developed bioengineered stem cells are IPS cells (Nelson et al. 2010). IPS cells generation has been reported for mouse (Takahashi \& Yamanaka 2006), human (Park et al. 2008), rat (Liao et al. 2009), monkey (Liu et al. 2008) and recently in the horse (Nagy et al. 2011), suggesting that virtually any mammalian species can be used for IPS cell derivation. With the advent of IPS technology, the limitations related to the use of ESCs and MSCs could be addressed by the pluripotent potential of bioengineered stem cells that are derived from autologous sources. Utilizing IPS-based technology, all lineages of the adult body have become viable targets for replacement. IPS cells enable the ability to genetically repair sequence defects through homologous recombination, which then produces healthy stem cells devoid of the original disease causing genetic impairment. Thereby, the ability to reproducibly generate unlimited selfderived progenitors that avoid immune intolerance is a unique feature. However, the unlimited differentiation potential of IPS is similar to ESCs, and thus the risk of dysregulated growth and teratoma formation requires stringent safeguards (Nelson et al. 2008). Moreover, beyond the common challenges of natural pluripotent stem cells, IPS cells also contain genetic modification as a consequence of the strategy used for reprogramming or spontaneously acquired cytogenetic abnormalities due to extensive in vitro manipulation. The long-term implications of nuclear reprogramming are yet to be determined as this technology is in the early stages of development.

The disadvantages of ESCs, BMMSCs and IPS have accelerated the search for alternative sources of stem cells as well as UC blood (UCB), Wharton's jelly (WJ) and amniotic fluid (AF). In human medicine, the use of UCB tissue as a source of MSCs can be traced back to 2000: in this year Erices et al. (2000) showed that cells from UCB were able to give rise to two types of adherent cells, one of which expressed antigens typical of MSCs. Equine UCBMSCs have been isolated for the first time by Koch et al. (2007). Authors observed that isolated cells were able to differentiate in vitro into osteocyte, adipocyte and chondrocyte (Koch et al. 2007), but no studies on their molecular characterization have been performed. Only recently, Lovati et al. (2011), using RT-PCR, observed that MSCs from UCB expressed CD105, CD29 and CD44, and were negative for haematopoietic marker CD34. No further investigations have been carried out on equine UCBMSCs molecular characterization. 
The UC intervascular stroma consists of so-called 'mucous' or mesenchymal connective tissue, also called Wharton's Jelly (WJ). WJ develops from extraembryonic mesoderm, binds and encases the umbilical vessels, protecting them from twisting and compression during pregnancy. It also has angiogenic and metabolic roles for the umbilical circulation. Since 1990, stromal cells, which basically resemble mesenchymal fibroblasts found elsewhere during in utero development, were identified in human WJ (Takechi et al. 1993, Nanaev et al. 1997). Stemness of these cells has been demonstrated by in vitro differentiation (Lu et al. 2006) and identification of MSCs membrane-specific markers. Furthermore, these cells did not express haematopoietic lineage markers such as CD34, CD45 and CD14 (Wang et al. 2004, Weiss et al. 2006, Secco et al. 2008). In the equine species, WJMSCs have been isolated in 2007 by Hoynowski et al. Authors identified isolated cells like MSCs due to their osteogenic, chondrogenic and adipogenic potency when cultured in induction media. As suggested by Dominici et al. (2006), the expression of markers associated with stem cells from embryonic and ASCs has been observed by flow cytometry (Hoynowski et al. 2007).

Since 1980, multiple cell types from embryonic and extra-embryonic tissues were identified in AF (Gosden 1983), but only in 2000 cells with an immunocytochemical profile of mesenchymal, fibroblast/myofibroblast cell lineages have been isolated and expanded in vitro (Kaviani et al. 2001). Prusa et al. (2004) observed the presence of a cell distinct population expressing POU5F1 (Oct4), a marker for pluripotent stem cells known to be expressed in ESCs, in human AF (Pesce \& Scholer 2001). The mechanisms involved in the POU5F1 regulation in ESC have been widely investigated, but in the adult stage (including post-natal and fetus stages) POU5F1 function has not been identified even though it has been associated with the undifferentiated pluripotent state of stem cell populations derived from various adult human tissues or organs such as bone marrow-derived multipotent adult progenitor cells. Furthermore, positive expression of mesenchymal markers such as CD90, CD105 and CD73; and negative expression of haematopoietic markers such as CD45, CD34 and CD14 have been observed (In't Aker et al. 2003, Tsai et al. 2004, De Coppi et al. 2007). Recently, De Coppi et al. (2007) showed that human and rodent AF-derived stem cells (AFMSCs) are positive for c-kit (CD117), that is also expressed in the heart (Beltrami et al. 2003) and retina stem cells (Koso et al. 2007), indicating that the c-kit receptor can identify a stem cell population within different organs. The c-kit receptor is a protein tyrosine kinase that binds a cytokine named stem cell factor. This cytokine and its receptor have been involved in embryogenesis, carcinogenesis, spermatogenesis, melanogenesis and play an important role in the haematopoiesis during embryo development. AFMSCs are thought to originate from the developing fetus and be in an intermediate stage between ESCs and lineagerestricted ASCs (De Coppi et al. 2007), but the exact origin of these cells is unclear. However, due to their adipogenic, osteogenic, myogenic, endothelial, neurogenic, hepatic, chondrogenic and renal differentiation potency (Tsai et al. 2004, Perin et al. 2007), AFMSCs may be a readily available source similar to ESCs for large numbers of different cells progenitors (De Coppi et al. 2007). In addition, AFMSCs have not shown tumorigenicity, thus making them an exciting new source of regenerative cells (You et al. 2008).

Although there are promising results in human field, few studies are available on characterization and differentiation potential of these cells in domestic animals. The aim of this study was to optimize the isolation and culture of equine MSCs from AF, UCB and WJ. Self-renewal ability and multilineage differentiation capability have been further evaluated. We herein aimed to widen the knowledge of equine MSCs from fetal fluid and membranes characterization by testing several molecular markers by flow cytometry. The markers tested in the present study were chosen among those suggested by the International Society for Cytotherapy (ISC; Dominici et al. 2006). In addition, CD44 was screened because of its role in MSC migration (Sackstein et al. 2008) and its correlation with 'stemness' in other MSC populations (Strem et al. 2005). Due to no commercially available species-specific antibodies existence to characterize equine stem cells, in the present study antibodies for human markers were involved using cross-reactivity of the antibodies among different species, such as recently reported by Park et al. (2011). By an increasingly more detailed analysis of the equine AFMSC phenotypic profile we hope that, as has been done for human MSCs, a list of minimum cultural and phenotypic criteria can be drawn up as soon as possible.

\section{Results \\ Animals}

In the equine species, the fetus was normally born in anterior presentation, dorsal position and extended (head, neck and forelimbs) posture. Failure to observe the fluid-filled amnion (which may be visible only during contractions) protruding from the vulva after 5 min from the beginning of the second stage of parturition indicates that we are probably facing a dystocia. In the present work, AF, UCB and WJ have been recovered from mares that underwent an eutocic (normal) parturition, without induction, and which delivered healthy, viable foals, as showed by an APGAR score $\geq 9$ (Vaala 2006). Samples were obtained from 13 mares and no complications for both mares and foals were encountered upon $\mathrm{AF}, \mathrm{CB}$ and UC sampling at delivery. 


\section{Sampling and cell culture}

AF samples from 10/13 (77.0\%) donor mares have been recovered: on average, we obtained 35.0 $\pm 23.5 \mathrm{ml} /$ mare (range: $15-50 \mathrm{ml}$ ). We isolated cells using a Percoll density-gradient centrifugation for eliminating urinary crystals, deposits of minerals and small debris, which are present in AF during last gestation period and can damage cells during in vitro culture. To obtain the clear buffy coat layer, AF was diluted with PBS. After washing pellets were seeded in culture dishes. Adherent fibroblastoid spindle-shaped cells growing in monolayer were isolated in 7/10 (70.0\%) samples (Fig. 1A).
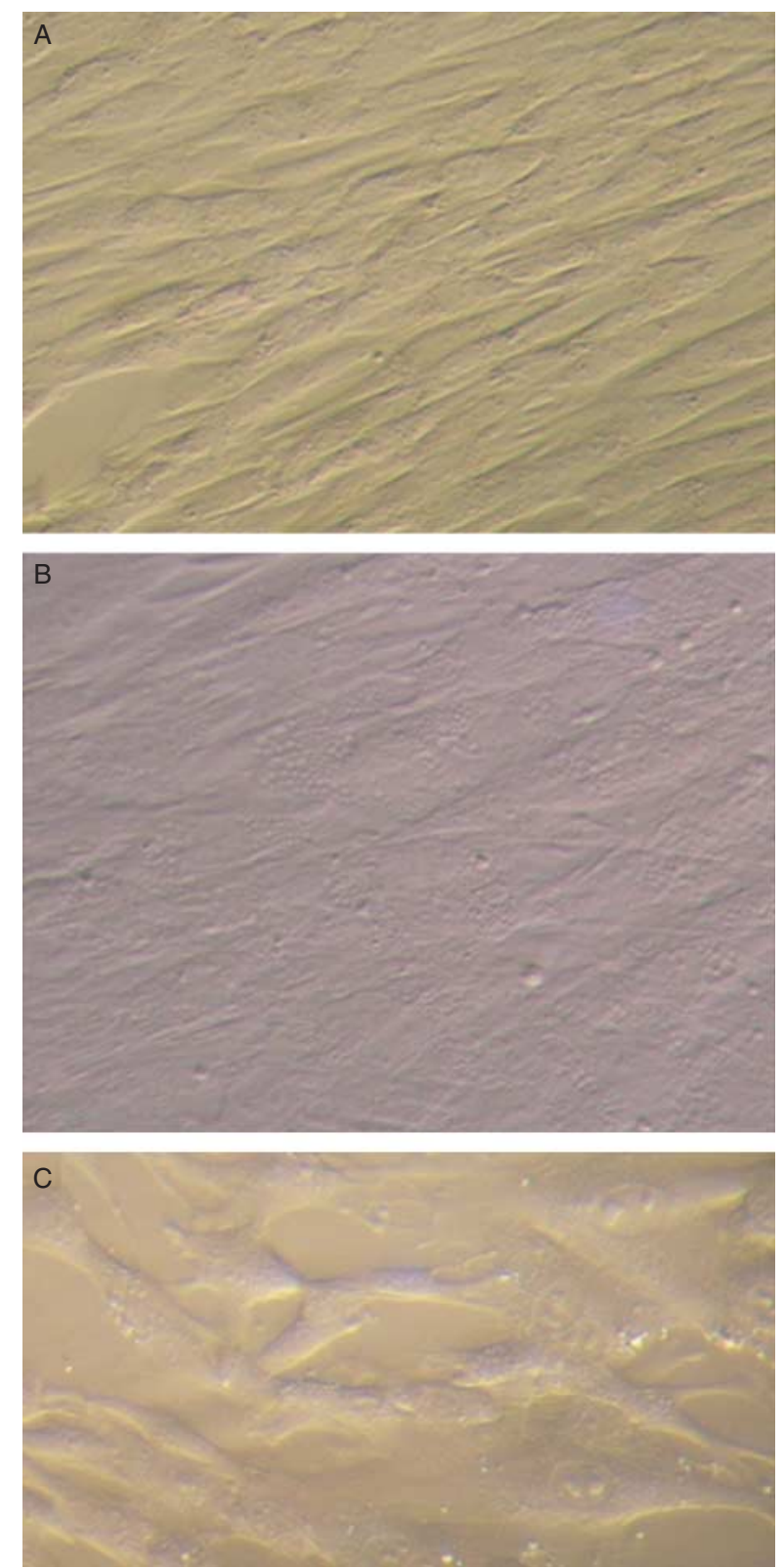

Figure 1 Monolayer of rapidly expanding adherent spindle-shaped fibroblastoid cells compatible with undifferentiated MSC. (A) AF, (B) UCB and (C) WJ. Magnification $\times 10$.
UCB samples (15-55 ml; mean 36.7 $\pm 13.9 \mathrm{ml}$ ) were recovered from $8 / 13$ mares $(61.5 \%)$, due to the early umbilical vein collapse. From equine UCB, cells have been isolated by Percoll density-gradient: to obtain a clear buffy coat, UCB was diluted with PBS and harvested mononuclear cells were washed several times to remove platelets and red blood cells. Adherent spindle-shaped cells have been isolated in $6 / 8(75.0 \%)$ samples (Fig. 1B); and in one sample (1/8: 12.5\%) no adherent cells were observed.

Immediately after foal detachment, UC samples have been recovered (length $\sim 15 \mathrm{~cm}$ ), after 13/13 (100\%) deliveries. UC samples were rinsed in antibiotic and ethanol solutions and $\mathrm{WJ}$ has been isolated: the mean weight of recovered jelly was $5.0 \pm 3.7 \mathrm{~g}$ (range: 1.8 $11 \mathrm{~g}$ ). The jelly was minced and digested using an enzymatic solution; after washing in PBS plus fetal bovine serum (FBS), mononuclear cells were seeded in culture dishes. Adherent cells with MSC morphology have been isolated in 8/12 (66.7\%) samples (Fig. 1C); and $1 / 13(7.7 \%)$ of collected UC was not processed for cell isolation due to the absence of WJ.

The partum canal and delivery environment represent a non-sterile condition for horses. As a consequence UC and amniotic tissue are exposed to significant bacterial and yeasts contaminations. To prevent from these contaminations, for $\mathrm{AF}$ and $\mathrm{UCB}$ sampling, we used sterilized syringes and gloves and pulled down AF quickly. Despite the precautions used, in $3 / 10(30.0 \%)$ AF samples no adherent cells have been observed due to bacteria $(1 / 3)$ and yeasts $(2 / 3)$ contaminations. On the contrary, only in $1 / 8(12.5 \%)$ UCB samples no adherent cells have been observed. Lower isolation rate due to external contaminations has been observed in WJ (4/12 samples: $33.3 \%)$. In this study, to avoid contaminations without killing cells, UC samples were immersed in a $70 \%$ ethanol solution for 10 min but it was not sufficient to completely eliminate contaminations.

Undifferentiated cells of all lines have been passaged up to eight times and population-doubling times (DTs) have been calculated. DT assay showed that AF, UCB and WJMSCs were able to divide for an extensive period in vitro. During P0 to P8, AF cells showed a mean DT of $2.3 \pm 1.0$ days/CD (range: $0.6-4.5$ days; Fig. $2 \mathrm{~A}$ ). By P8, total mean $\mathrm{CD}$ was $37.3 \pm 3.0$ (Fig. 2B). One line of equine AFMSCs was cultured up to 118 days (15 passages) during which the cells reached 58.7 CD. Considering the same culture passages (P0-P8), the mean DT showed by equine UCBMSCs was 2.6 \pm 1.3 days/CD (range: $1.1-5$ days; Fig. $2 \mathrm{C}$ ) and it was statistically higher $(P<0.05)$ than that showed by equine AFMSCs (2.3 \pm 1.0 days/CD). By P8, UCBMSCs celldoubling number (CD) was $34.4 \pm 2.3$ (Fig. 2D). Adherent spindle-shaped cells isolated from equine WJ showed a mean DT $(2.0 \pm 0.6$; range: $1.2-4$ days; Fig. 2E) significantly lower than those observed in 

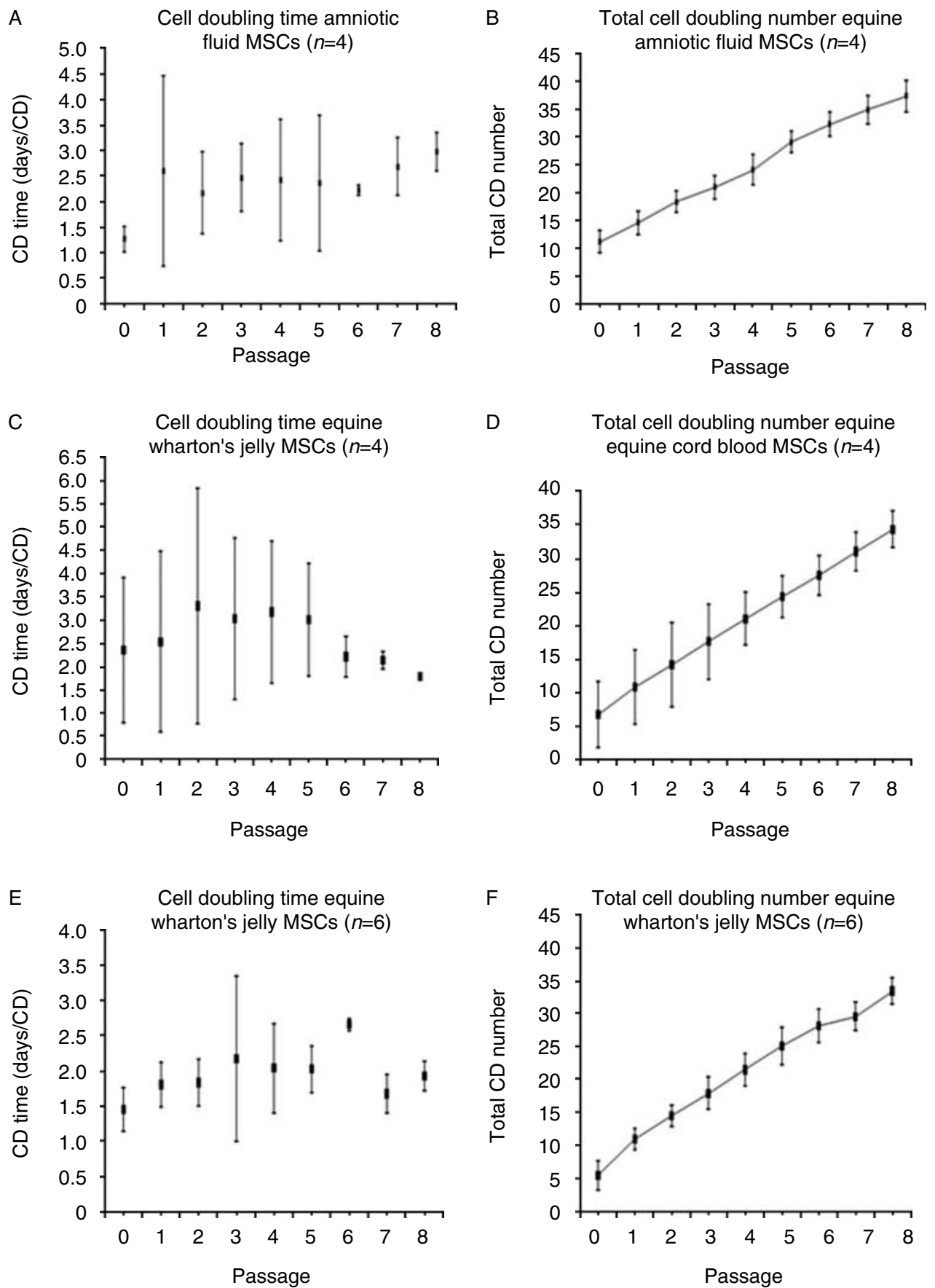

Figure $2 \mathrm{CT}$ and CD of cultured primary and passaged MSCs. All values reflect the mean \pm s.D. (A and B) AFMSCs: data were compiled from seven cell cultures. DT of primary cells and subsequent passages was not significantly different $(P>0.05)$. The mean MSC doubling number at P8 was 37.3 \pm 3.0. (C and D) UCBMSCs: data were obtained from four cell cultures. DT of primary cells and subsequent passages was not significantly different $(P>0.05)$. The mean MSC doubling number at P8 was 34.4 \pm 2.3 . (E and F) WJMSCs: data were compiled from six cell cultures. DT of primary cells and subsequent passages was not significantly different $(P>0.05)$. The mean MSC doubling number at $P 8$ was $37.4 \pm 2.0$.

AFMSCs and UCBMSCs culture $(2.0 \pm 0.6$ vs 2.6 \pm 1.3 days/CD vs $2.3 \pm 1.0$ days/CD respectively; $P<0.05)$. In this cell line, by $P 8, C D$ was $37.4 \pm 2.0$ (Fig. 2F). Despite different DTs, no statistically significant differences have been found in $C D$ among the three different cell lines. Furthermore, no lag phase has been observed during in vitro culture of $\mathrm{AF}, \mathrm{UCB}$ and WJMSCs: in fact no statistically significant differences in the number of $C D$ have been found among different culture passages $(P>0.05)$. The results obtained indicate that equine AFMSCs, UCBMSCs and WJMSCs had selfrenewal capacity. 
Table 1 Flow cytometry analysis of P3 MSCs from AF, UCB and WJ for the surface markers CD90, CD105, CD73, CD44, CD14, CD34 and CD45.

\begin{tabular}{|c|c|c|c|c|c|c|c|}
\hline Tissue & CD90 (\%) & CD105 (\%) & CD73 (\%) & CD44 (\%) & CD14 (\%) & CD34 (\%) & CD45 (\%) \\
\hline $\mathrm{AF}$ & 82.2 & 78.1 & 4.0 & 98.4 & 0.9 & 1.8 & 4.2 \\
\hline UCB & 90.3 & 83.2 & 0.1 & 96.9 & 0.7 & 7.5 & 7.9 \\
\hline WJ & 93.4 & 93.2 & 0.0 & 97.2 & 0.2 & 0.4 & 0.4 \\
\hline
\end{tabular}

\section{Immunophenotypic characterization by flow cytometry}

ISC postulated that MSCs show positive expression for CD73, CD90 and CD105; and negative expression for CD14, CD34 and CD45 (Dominici et al. 2006). As there are no equine-specific antibodies for flow cytometry, in the present study we used anti-human antibodies, routinely used by Immunohaematology and Transfusion Center equipe, using cross-reactivity of antibodies among different species. The antibodies efficiency was verified by performing a control on circulating equine lymphocytes. As expected, considering the results obtained with human lymphocytes, adult and haematopoietic markers used have not been expressed by these cells. Unexpected data have been registered for CD45 and CD73 that were negative also for lymphocytes (data not shown). Furthermore, we compared amino acid sequences using Basic Local Alignment Search Tool (Blast). Our results, as summarized in Table 1, showed a similar expression pattern of MSC phenotype, but different levels of reactivity of antibodies tested have been observed. In particular, cells were reactive to surface markers CD90 and CD105 in all cell lines evaluated (Fig. 3). MSCs also demonstrated a marker reaction with CD44 (Table 1 and Fig. 3), a cell-surface glycoprotein having a role in MSCs migration. Others markers for haematopoietic cell were not expressed (Table 1 and Fig. 3). Due to negative lymphocytes CD45 and CD73 expression and the lack of horse CD45 and CD73 sequence, for these markers cross-reactivity could not be confirmed, as well as its negative expression by equine MSCs.

\section{In vitro differentiation}

To characterize isolated cells, we further performed trilineage differentiation assay. According to ISC, we induced chondrogenic, osteogenic and adipogenic differentiation culturing each lineage for several days in induction media.

Chondrogenic induction has been performed in monolayer culture and after 21 days cell Alcian Blue staining has been performed to assess differentiation. Alcian Blue staining is usually used to confirm mucosubstances and acetic mucins deposition. We found that induced cells were positive for Alcian Blue (Fig. 4A). The negative controls kept in regular culture medium showed no change in their morphology, no cells stained positive for Alcian Blue (Fig. 4B).

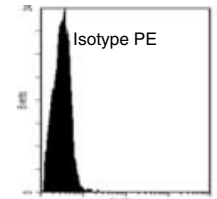

$\mathrm{AF}$
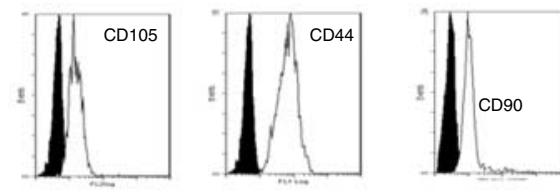

CB
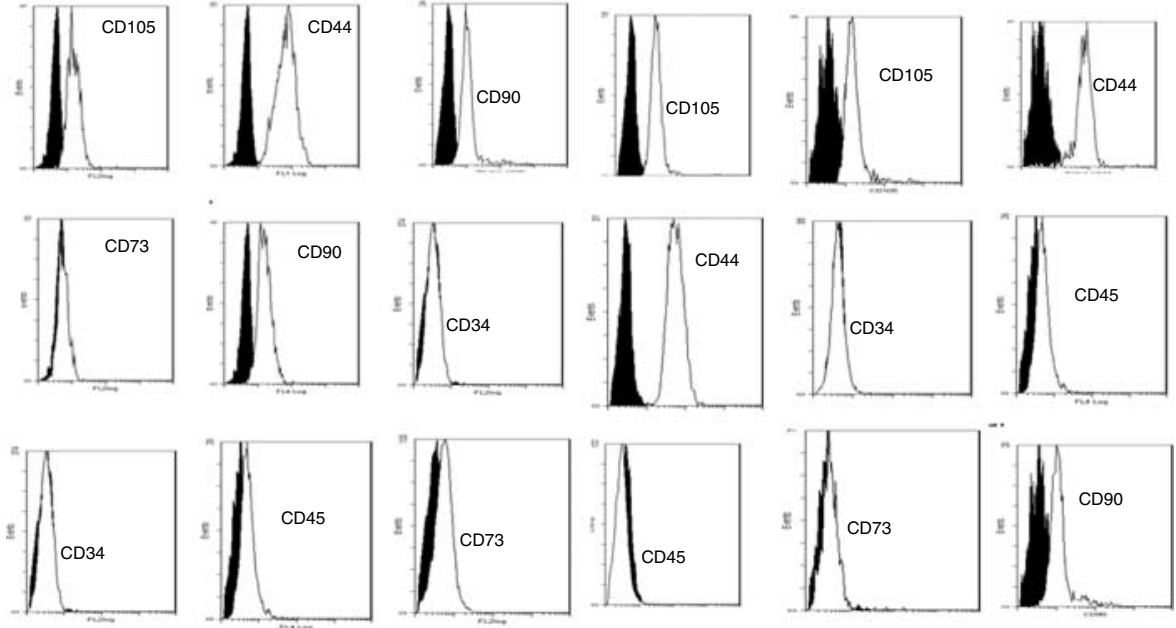

Figure 3 Overlay histograms of cytometry analysis. In black isotypic controls are represented. Empty histograms represent the analysis with mAbs on mesenchymal cell culture. 

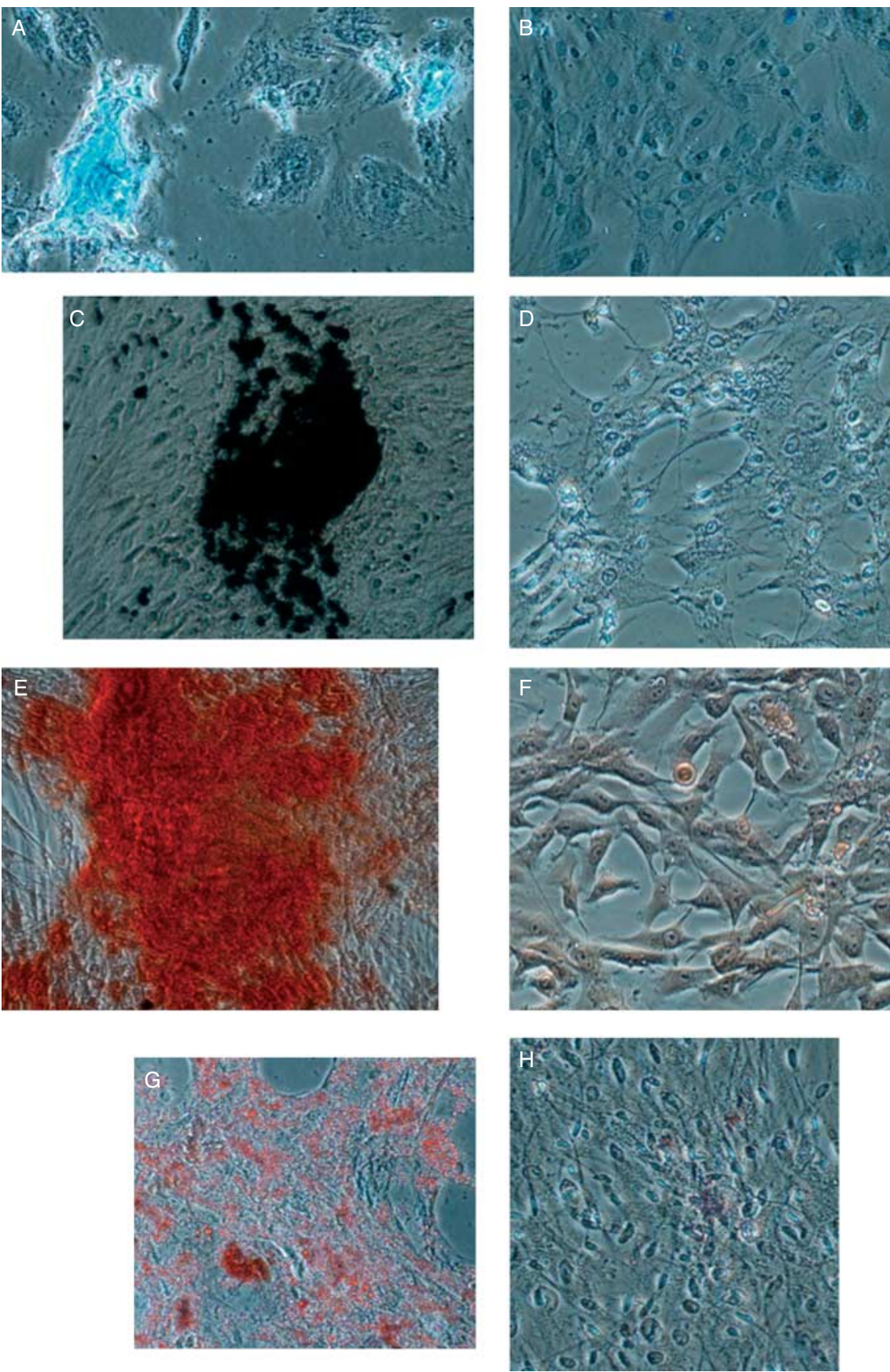

Figure 4 In vitro differentiation studies. (A) Chondrogenic induction in equine $\mathrm{AF}$ progenitors over 3 weeks: Alcian Blue staining of glycosaminoglycans in cartilage matrix. Magnification $\times 10$. (B) Chondrogenic control: equine AF cells cultured in regular medium for 21 days maintained normal morphology and stained negative for Alcian Blue. Magnification $\times 10$. (C) Osteogenic induction in equine WJ progenitors over 3 weeks: von Kossa staining of extensive extracellular calcium deposition. Magnification $\times 20$.

(D) Osteogenic control: equine WJ cells cultured in standard medium for 21 days maintained normal morphology and stained negative for von Kossa staining. Magnification $\times 10$. (E) Osteogenic induction in equine $\mathrm{AF}$ progenitors over 3 weeks: Alizarin Red S staining of extensive extracellular calcium deposition. Magnification $\times 10$. (F) Osteogenic control: equine AF cells cultured in regular medium, after 21 days presented normal morphology and stained negative for Alizarin Red S staining.

Magnification $\times 10$. (G) Adipogenic induction in equine $\mathrm{CB}$ progenitors over 3 weeks: Oil red $\mathrm{O}$ staining of extensive intra-cellular lipid droplet accumulation. Magnification $\times 20$. (H) Adipogenic control: equine CB cells, after 21 days of culture in standard medium presented normal morphology and stained negative for Oil red $\mathrm{O}$ staining. Magnification $\times 10$.
To determine osteogenesis, isolated cells were cultured in osteogenic induction medium and growth medium was used as a control. Cells were maintained in induction condition for 3 weeks. Significant calcium depositions were detected in induced cells compared to control using Von Kossa staining and Alizarin Red (Fig. 4C and D).

To show adipogenic potency, cells were cultured in adipogenic induction medium for 3 weeks. To detect fat droplets and quantify adipogenesis, we stained cells with Oil Red $\mathrm{O}$, a fat-soluble dye. Cells maintained in induction medium resulted positive for Oil Red O, while undifferentiated control cells did not stain for fat droplets. UCBMSCs showed a greater adipogenic potential than AFMSCs and WJMSCs, characterized by a greater accumulation of lipid vacuoles. Further investigation using RT-PCR is needed to verify if different differentiation capacities exist among these three cell lines. 


\section{Discussion}

Isolation and characterization of stem cells derived from various tissues and sources are important issues in stem cell field. WJ is the mature connective tissue surrounding umbilical vessels: it is composed of myofibroblast-like stromal cells, collagen fibres and proteoglycans (Kobayashi et al. 1998). Recently, researchers have focused on it as a potential new source of MSCs both in humans and horses (Hoynowski et al. 2007, Karahuseyinoglu et al. 2007, Passeri et al. 2009), but the efficient isolation of cells that truly express MSC characteristics has been somewhat controversial. Controversial results have also been obtained for cells isolated from equine UCB (Kock et al. 2007, Cremonesi et al. 2008), and no report has been found on their characterization using criteria postulated by ISC in this species. Due to its contact with the developing fetus, AF contains large numbers of suspended cells including stem cells (In't Anker et al. 2003, De Coppi et al. 2007). To our knowledge, recently, only two studies have been published on horse AF-derived progenitor cells, whereas it is considered a rich source of MSCs in human beings. We compared WJ, AF and UCB as viable, accessible and not risky sources of MSCs in equine. In the present study high initial sample volumes of AF, UCB and tissue have been easily collected at the delivery, without any invasiveness for the mare or for the foal, and high numbers of viable nucleated cells from these sources have been isolated, except for some failure samples occurring in yeasts/bacterial contaminations as previously reported by other authors (Passeri et al. 2009, Lovati et al. 2011). The isolation rate obtained in the present study by centrifuging UCB on a Percoll densitygradient was lower than that obtained by Koch et al. (2009) using a PrepaCyte-EQ density gradient (100\%). Given the influence that laboratory conditions may have on the outcome of projects, in the future it would be appropriate to compare, under the same conditions, the isolation method used in this study with those reported by other authors. On the other hand, data reported for human UCB (Kern et al. 2006) are lower than that of ours. This difference could be due to various factors, such as duration of parturition, recovery protocol, time between sample collection and processing in the laboratory: these factors determined viable cells reduction because of their transition to the fetus or their death.

We cultured cells isolated from equine $\mathrm{AF}, \mathrm{WJ}$ and UCB for several days, from P0 to P8, and they showed a typical MSC morphology, having spindle shape and adherent characteristics, as postulated by ISC (Dominici et al. 2006). Regarding cells proliferation, WJMSCs showed a higher expansion rate compared to UCBMSCs and AFMSCs: results observed are similar to those reported in human medicine for UCBMSCs and WJMSCs (Sarugaser et al. 2005, Karahuseyinoglu et al. 2007), but not for AFMSCs (Tsai et al. 2004). Different DTs between human and horse AFMSCs could be determined during the period of pregnancy in which the drawing was made. Human AF samples were recovered by amniocentesis, at the beginning of the second trimester of pregnancy, therefore, human AFMSCs could show DT more similar to ESCs. UCBMSCs DT registered in our laboratory was higher than that reported by Koch Research Group (Koch et al. 2007, 2009). The difference could be determined by the higher concentration of FBS used by the authors during in vitro culture (10 vs $30 \%$ ). FBS is a mixture of high-molecular-weight molecules that may promote or inhibit cell growth and differentiation (Barnes et al. 1987, van der Valk et al. 2004); however, this composition is largely unknown in both qualitative and quantitative terms, and moreover FBS may be a vehicle of known pathogens and unknown infectious agents (Schallmoser et al. 2007). Different from that observed by Lovati et al. (2011) and Eloit (1999), in our study all cell lineages showed a similar fold expansion during all passages (P0-P8) and WJMSCs were not affected by the trypsin detachment as reported by the other authors. The discrepancy in WJMSCs expansion is likely due not only to different culture conditions, but also to the different selections of cord tissue to be processed. The immature cells that retain the ability to proliferate were located close to the amniotic surface, whereas highly differentiated, non-proliferating fibroblasts were located in closer proximity to the umbilical vessels (Nanaev et al. 1997): in our study, only cord jelly, closer to amniotic surface, was digested, while Lovati et al. (2011) did not distinguish between near or far from umbilical vessel portion thus the cell population cultured was very heterogeneous and this could explain the lower cell doubling.

In the present study, we also demonstrated the multipotent capability of equine AFMSCs, UCBMSCs and WJMSCs. The choice of lineages differentiation was made based on the principles established by the ISC (Dominici et al. 2006). Chondrogenic and osteogenic differentiations were carried out with a view to future clinical application of these cells in injured horses, as previously supported by Berg et al. (2009). All three cell lines differentiated in chondroblasts, osteoblasts and adipocytes, as demonstrated by staining, performed after 21 days of culture in appropriate medium; control cells did not stain at all and only the background colour remained. While a lack, also testing different protocol, in adipogenic efficiency of equine AFMSCs has been reported in a previous study (Park et al. 2011), in our experiment equine AFMSCs showed an adipogenic potential similar to that observed in equine WJMSCs, while UCBMSCs seem to show a greater adipogenic potential than AFMSCs and WJMSCs, characterized by a greater accumulation of lipid vacuoles. Further studies, 
using different induction protocols and evaluating differentiation assay by cytology and RT-PCR, are necessary to verify if these different findings are due to different laboratory conditions or if in equine the conditions for $\mathrm{AF}, \mathrm{WJ}$ and UCBMSCs promote one type of differentiation lineage rather than other, as suggested by Park et al. (2011).

In the present work, phenotypic characterization of equine AF, UCB and WJMSCs was carried out by the expression analysis of several surface MSC markers. We choose to investigate cells at the third culture passage, as they have reached a sufficient level of homogeneity at this stage. As there are no equine-specific antibodies for flow cytometry, we used antibodies for human markers. To provide evidence for inter-species crossreactivity, the similarity of $C D$ markers was identified comparing the amino acid sequence, as already been reported by de Mattos Carvalho et al. (2009). Furthermore, as suggested recently by Pascucci et al. (2011) we used equine circulating lymphocytes as control. In the present study, high percentage of equine $\mathrm{AF}, \mathrm{UCB}$ and $\mathrm{WJ}$ cells population expressed MSC surface markers CD90 and CD105. In addition, flow cytometry revealed that the majority of analysed cells were positive also for CD44. Our data are similar to those reported by Park et al. (2011) for equine AFMSCs tested using anti-human antibodies; moreover, these markers are present in human MSCs and have also been found in equine MSCs isolated from adipose tissue (de Mattos Carvalho et al. 2009, Pascucci et al. 2011). These findings confirm that concerning CD90 and CD44 a high phenotypic similarity do exist among MSCs isolated from different species and sources (Strem et al. 2005).

A lack of reactivity with haematopoietic markers CD34 and CD14, which cross-reaction was confirmed by lymphocytes investigation, indicates that isolated cells are negative for haematopoietic progenitors. On the other hand, the lack of reactivity of equine cells and lymphocytes with the haematopoietic markers CD45 and MSC with marker CD73 probably indicates that the human-directed reagents do not cross-react with their corresponding equine epitopes. These findings need further investigation to assess if, in particularly, the lack of CD73 expression is due to the lack of cross-reactivity or is a species-specific feature as interpreted by Pascucci et al. (2011).

From results obtained in this study, we suggest the existence of alternative sources of multipotent cells in equine. Differentiation of $\mathrm{AF}, \mathrm{UCB}$ and WJMSCs into adipocytes and, above all, into osteocytes and chondrocytes underlies their possible use for regenerative medicine in injured horses. Further study will be necessary to evaluate the expression of cell antigens and the possible use of these tissues as allogenic source of MSCs.

\section{Materials and Methods}

\section{Materials}

All chemicals were obtained from Sigma-Aldrich, plastic dishes and tubes from Sarstedt, Inc. (Newton, NC, USA) unless otherwise noted.

\section{Animals}

Samples were obtained from 13 standardbred mares, between 6 and 15 years of age, belonging to one stable location near the Faculty of Veterinary Medicine of Bologna University, or housed at the Equine Perinatology Unit 'Stefano Belluzzi', University of Bologna, for attending delivery. Experimental procedures were carried out in accordance with DL 116/92 and were approved by the Ethics Committee at the University of Bologna and by the Ministry of Health.

\section{Sampling and MSCs isolation}

\section{Amniotic fluid}

AF samples were taken soon after foal or placenta membranes passed through vulva, using a sterile 18 gauge needle mounted on a $60 \mathrm{ml}$ sterile syringe (IMI, Padua, Italy), containing $1 \mathrm{ml}$ of EDTA solution to prevent clot formation that could affect cell isolation. Samples were stored at $4{ }^{\circ} \mathrm{C}$ and further processed within $12 \mathrm{~h}$. Briefly, each sample was diluted 1:1 with Dulbecco's Phosphate Buffer Solution (DPBS) containing $100 \mathrm{IU} / \mathrm{ml}$ penicillin and $100 \mu \mathrm{g} / \mathrm{ml}$ streptomycin. The obtained solution was centrifuged (Heraeus Megafuge 1.0R; rotor: Heraeus \#2704; ThermoFisher Scientific Inc.) for $15 \mathrm{~min}$ at $470 \mathrm{~g}$. Supernatant was carefully removed and the pellet was re-suspended in $5 \mathrm{ml}$ of culture medium containing DMEM and TCM199 (1:1), 10\% (v/v) FBS (Gibco; Invitrogen Corporation), $100 \mathrm{IU} / \mathrm{ml}$ penicillin and $100 \mu \mathrm{g} / \mathrm{ml}$ streptomycin. Cells were isolated by carefully loading sample on $5 \mathrm{ml}$ of $70 \%$ Percoll solution in a $50 \mathrm{ml}$ polypropylene tube, centrifuging for $30 \mathrm{~min}$ at $25^{\circ} \mathrm{C}$ at $1880 \mathrm{~g}$; the interphase was collected after aspirating and discarding the supernatant, washed with $20 \mathrm{ml}$ of culture medium and centrifuged at $470 \mathrm{~g}$ for $10 \mathrm{~min}$ at $25^{\circ} \mathrm{C}$. The supernatant was aspirated and cells were washed with culture medium a second and third time. Cells were then re-suspended in $1 \mathrm{ml}$ of culture medium and counted by haemocytometer.

\section{Umbilical cord blood}

CB was collected immediately after foaling and before the UC breaks spontaneously or was broken according to management protocol. Venipuncture of the umbilical vein was performed with a 21 guage hypodermic needle attached to a $60 \mathrm{ml}$ sterile syringe (IMI), containing $1 \mathrm{ml}$ of heparin (Eparina Vister $5000 \mathrm{IU} / \mathrm{ml}$; Marvecs Pharma, Milan, Italy) as anti-coagulant. Blood samples were stored at $4{ }^{\circ} \mathrm{C}$ for at the least $12 \mathrm{~h}$. Each sample was diluted 1:1 with DPBS containing $100 \mathrm{IU} / \mathrm{ml}$ penicillin and $100 \mu \mathrm{g} / \mathrm{ml}$ streptomycin. The solution was centrifuged (Heraeus Megafuge 1.0R; rotor: Heraeus \#2704) for $15 \mathrm{~min}$ at $470 \mathrm{~g}$. Supernatant was removed and the pellet was re-suspended in $5 \mathrm{ml}$ of culture medium. The mononuclear cell fraction was isolated by 
carefully loading sample on $5 \mathrm{ml}$ of $70 \%$ Percoll solution in a $50 \mathrm{ml}$ tube, centrifuging for $30 \mathrm{~min}$ at $1880 \mathrm{~g}$ at $25^{\circ} \mathrm{C}$. The interphase was then collected after aspirating and discarding the supernatant washed with $20 \mathrm{ml}$ of culture medium by centrifuging at $470 \mathrm{~g}$ for $10 \mathrm{~min}$ at $25^{\circ} \mathrm{C}$. The supernatant was aspirated and cells were washed twice with culture medium. Cells were then re-suspended in $1 \mathrm{ml}$ of culture medium and counted by haemocytometer.

\section{Wharton's Jelly}

Immediately after breaking the $U C$, the part closest to the Colt, characterized by an abundant amount of WJ, was severed. Samples were stored in DPBS containing $100 \mathrm{IU} / \mathrm{ml}$ penicillin and $100 \mu \mathrm{g} / \mathrm{ml}$ streptomycin, at $4{ }^{\circ} \mathrm{C}$ for at the latest $12 \mathrm{~h}$. UC was disinfected by immersing for $10 \mathrm{~min}$ in $70 \%$ ethanol. In a laminar flow hood, tissue was rinsed by repeated immersion in DPBS and WJ was isolated, weighed and minced finely $(0.5 \mathrm{~cm})$ by sterile scissors. Minced WJ was transferred into a $50 \mathrm{ml}$ polypropylene tube, to which was added $1 \mathrm{ml} / 1 \mathrm{~g}$ sample of a digestion solution $(0.1 \%$ $(\mathrm{w} / \mathrm{v})$ collagenase type I (Gibco, Invitrogen Corporation), dissolved in DPBS solution and sterilely filtered). The tissue and digestion solution were mixed thoroughly, incubated in a $37^{\circ} \mathrm{C}$ water bath for $1-2 \mathrm{~h}$, and mixed every $15 \mathrm{~min}$. After incubation, collagenase was inactivated by diluting 1:1 with DPBS plus $10 \%$ (v/v) FBS. The solution obtained was filtered and undigested tissue was discarded. Nucleated cells were pelleted at $470 \mathrm{~g}$ for $10 \mathrm{~min}$. The supernatant was discarded, pellet was re-suspended in $5 \mathrm{ml}$ of culture medium and spun at $470 \mathrm{~g}$ for $10 \mathrm{~min}$ to wash cells. This operation was repeated three times. After the last wash, cell pellet was re-suspended in $1 \mathrm{ml}$ of culture medium and cell concentration was counted by haemocytometer.

\section{Cell doubling method}

Primary cells were plated in a $25 \mathrm{~cm}^{2}$ flask at a maximum density of $5 \times 10^{4}$ cells $/ \mathrm{cm}^{2}$ and incubated in a $5 \% \mathrm{CO}_{2}$ humidified atmosphere at $38.5^{\circ} \mathrm{C}$. The medium was completely replaced after $48 \mathrm{~h}$ in order to remove nonadherent cells. Next the medium was completely replaced every 3 days until the adherent cell population reached $\sim 80 \%$ confluence. At this point, the adherent primary MSCs were passaged by digestion with $0.05 \%(\mathrm{w} / \mathrm{v})$ trypsin, counted with a haemocytometer, and re-seeded as 'Passage $1^{\prime}$ (P1) at $25 \times 10^{3}$ cells $/ \mathrm{cm}^{2}$. For the subsequent passages, cells were inoculated in $5 \mathrm{~cm}^{2}$ flasks at $25 \times 10^{3}$ cells $/ \mathrm{cm}^{2}$ and allowed to multiply for 6-7 days to $90 \%$ confluence before trypsinization and successive passage. DT and CD were calculated from haemocytometer counts and cell culture time (CT) for each passage according to the following two formulae (Vidal et al. 2007):

$$
\begin{aligned}
& \mathrm{CD}=\ln \left(N_{f} / N_{i}\right) / \ln (2) \\
& \mathrm{DT}=\mathrm{CT} / \mathrm{CD}
\end{aligned}
$$

where $N_{f}$ is the final number of cells and $N_{i}$ the initial number of cells.

\section{Chondrogenic in vitro differentiation}

Expanded cells were harvested after three passages, washed in DPBS, and placed in a six-well plate at a density of $5 \times$ $10^{3}$ cells $/ \mathrm{cm}^{2}$ in chondrogenic induction medium, consisting of DMEM/TCM199, $100 \mathrm{IU} / \mathrm{ml}$ penicillin, $100 \mu \mathrm{g} / \mathrm{ml}$ streptomycin, $6.25 \mu \mathrm{g} / \mathrm{ml}$ insulin, $50 \mathrm{nM}$ ascorbate-2-phosphate, $0.1 \mu \mathrm{M}$ dexamethasone, $10 \mathrm{ng} / \mathrm{ml}$ human transforming growth factor (hTGF)- $\beta 1$ and $1 \% \quad(\mathrm{v} / \mathrm{v})$ FBS. Cells in monolayer were incubated for 3 weeks. As a negative control an equal number of cells were cultured in expansion media for 21 days. In both groups the medium was completely replaced every 3 days. After 3 weeks of culture, cells were fixed with $10 \%(\mathrm{v} / \mathrm{v})$ formalin for $1 \mathrm{~h}$ at room temperature (RT), then stained with Alcian Blue solution $(1 \%$ in $3 \%$ acetic acid (v/v), pH 2.5) for $15 \mathrm{~min}$ at RT. Alcian Blue staining acid mucosubstances and acetic mucins confirmed chondrogenic differentiation cytologically.

\section{Osteogenic in vitro differentiation}

Undifferentiated cells were induced towards the osteogenic lineage using the protocol described by Mizuno \& Hyakusoku (2003). Briefly, at passage 3 putative cells were seeded in a six-well plate at a density of $5 \times 10^{3}$ cells $/ \mathrm{cm}^{2}$ and cultured in base medium for $24 \mathrm{~h}$ to allow cell adhesion. After cells had adhered to the plate, they were treated with an osteogenic induction medium consisting of $10 \mathrm{mM}$ $\beta$-glycerophosphate, $0.1 \mu \mathrm{M}$ dexamethasone, $50 \mu \mathrm{M}$ ascorbate-2-phosphate and 10\% (v/v) FBS in DMEM/TCM199. DMEM/TCM199 supplemented with $10 \%$ FBS was used as a control medium. Media in both groups were completely changed twice a week. After 21 days of induction, cells were stained to confirm osteogenic differentiation.

\section{von Kossa staining}

In the osteogenic assay, later stage of osteogenesis, characterized by calcium deposition, was assessed 3 weeks after induction via von Kossa and Alizarin Red S stainings for detection of deposits of calcium or calcium salt. For von Kossa staining, cells were washed three times with PBS before cell fixation with $10 \%(\mathrm{v} / \mathrm{v})$ formalin for $1 \mathrm{~h}$ at RT. Cells were washed five times with distilled water before adding $1 \mathrm{ml}$ of $5 \%(\mathrm{w} / \mathrm{v})$ silver nitrate and exposing to yellow light for $15 \mathrm{~min}$. The wells were washed five times with distilled water. Calcium phosphate deposits stained black.

\section{Alizarin Red S staining}

To confirm osteogenic differentiation, Alizarin Red S staining was also performed for detecting calcium deposition. In brief, cells were rinsed with DPBS and fixed incubating in ice-cold ethanol $70 \%(\mathrm{v} / \mathrm{v})$ for $1 \mathrm{~h}$ at RT. After three washes with distilled water $1 \mathrm{ml}$ of $2 \%(\mathrm{w} / \mathrm{v})$ Alizarin Red S ( $\mathrm{pH} 4.1-4.3)$ solution was added. The plate was incubated at RT for $30 \mathrm{~min}$, then Alizarin Red S solution was removed and then the cells were rinsed four times with distilled water. 


\section{Adipogenic in vitro differentiation}

Adipogenesis was induced using protocol described by Mizuno \& Hyakusoku (2003) and Koch et al. (2007). Six-well culture plates were seeded at a density of $5 \times 10^{3}$ cells undifferentiated MSCs per $\mathrm{cm}^{2}$ of tissue culture surface area in $0.5 \mathrm{ml}$ of expansion medium per tissue culture surface. After $24 \mathrm{~h}$, medium was completely replaced with adipogenic induction medium consisting of $15 \%(\mathrm{v} / \mathrm{v})$ rabbit serum, $1 \mu \mathrm{M}$ dexamethasone, $0.5 \mathrm{mM}$ 3-isobutyl-1-methylxanthine (IBMX), $10 \mu \mathrm{g} / \mathrm{ml}$ bovine insulin, $0.2 \mathrm{mM}$ indomethacin in DMEM/ TCM199. After $72 \mathrm{~h}$ of culture, the IBMX supplement was removed from the medium. After 3 additional days, the dexamethasone supplement was removed from the medium, and cells were cultured for additional 15 days. Equal cell number was cultured in expansion medium for negative control. Both groups were maintained in culture for a total of 21 days and media were completely exchanged every 3 days. To asses adipogenic differentiation, cells were stained to evaluate the baseline formation of neutral lipid vacuoles stainable with Oil Red O. Medium was aspirated, cells were washed once with PBS then fixed with $10 \%(\mathrm{v} / \mathrm{v})$ formalin for $1 \mathrm{~h}$ at RT. The formalin was then replaced with $2 \mathrm{ml}$ of sterile water for a few minutes. Water was aspirated and replaced with $60 \%(\mathrm{v} / \mathrm{v})$ isopropanol for $5 \mathrm{~min}$ and then cells were covered with Oil Red O solution ( $0.3 \%$ in $60 \%$ isopropanol (v/v)). After $5 \mathrm{~min}$, cells were rinsed with distilled water and lipid vacuoles appeared red.

\section{Characterization of MSCs}

Cytofluorimetric analysis was performed to identify cell surface marker expression of equine MSCs. At passage 3, cells were labelled with the following mAbs: CD105, CD45, CD90, CD44, CD34, CD14 and CD73 (all from Beckman Coulter, Fullerton, CA, USA). Cells were also labelled with isotype control antibodies. Briefly, at $80 \%$ confluence, cells at P3 were washed twice with DPBS, harvested using $0.05 \%(\mathrm{w} / \mathrm{v})$ trypsin solution and aliquoted at a concentration of $0.5-10^{6} \mathrm{cell} / \mathrm{s} / \mathrm{m}$. Each aliquot was fixed and permeabilized using Reagent 1 of Intraprep Kit (Beckman Coulter, Miami, FL, USA) according to the manufacturer's instructions. Cells were stained for $30 \mathrm{~min}$ with either conjugated-specific antibodies or istotype-matched control mouse IgG (Table 2) at recommended concentrations. Labelled cells were washed twice in DPBS and fluorescence

Table 2 Primary antibodies and isotype used for flow cytometry.

\begin{tabular}{|c|c|c|}
\hline Markers & Primary antibody & $\lg$ \\
\hline CD44FITC & Mouse monoclonal & $\lg G 1$ \\
\hline CD90PC5 & Mouse monoclonal & $\lg G 1$ \\
\hline CD105PE & Mouse monoclonal & $\lg G 2 a$ \\
\hline CD73PE & Mouse monoclonal & $\lg G 1$ \\
\hline CD14PC5 & Mouse monoclonal & $\lg G 2 a$ \\
\hline CD45APC & Mouse monoclonal & $\lg G 1$ \\
\hline \multicolumn{3}{|l|}{ Isotype } \\
\hline PC5 & Mouse monoclonal & $\lg \mathrm{g} 2 \mathrm{a}$ \\
\hline FITC & Mouse monoclonal & $\lg G 1$ \\
\hline PE & Mouse monoclonal & $\lg G 1$ \\
\hline APC & Mouse monoclonal & $\lg \mathrm{G} 1$ \\
\hline
\end{tabular}

intensity was evaluated using an FC500 two-laser equipped cytometer (Beckman Coulter). All analyses were based on control cells incubated with isotype-specific IgGs to establish the background signal. Cross-reactivity of the antibodies used was screened using cultured human and horse MSCs. Furthermore, to verify cross-reactivity, control of circulating equine lymphocytes was carried out. The similarity of CD markers was also identified by comparing the amino acid sequences using Basic Local Alignment Search Tool (BLAST). Results were further analysed with the CXP dedicated program.

\section{Statistical analysis}

CT and CD are expressed as mean \pm s.D. Statistical analysis was performed using Statistics for Windows (Stat Soft, Inc., Tulsa, OK, USA). Data were analysed using one-way ANOVA for multiple comparisons. Significance has been assessed for $P<0.05$.

\section{Declaration of interest}

The authors declare that there is no conflict of interest that could be perceived as prejudicing the impartiality of the reported research.

\section{Funding}

This research was supported by University of Bologna (RFO: Ricerca Fondamentale Orientata).

\section{Acknowledgements}

The authors wish to thank Prof. Gaetano Mari (Department of Veterinary Medical Sciences, University of Bologna, Ozzano Emilia (BO), Italy), Dr Carolina Castagnetti (Equine Perinatology Unit, Department of Veterinary Medical Sciences, University of Bologna, Ozzano Emilia (BO) Italy) and Scuderia Trio Srl (Ozzano Emilia (BO), Italy), for the agreement of the sample collection. Thanks are also due to Dr Silvia Colleoni (AVANTEA Srl, Cremona, Italy) and Prof. Cesare Galli (Department of Veterinary Medical Scineces, University of Bologna, Ozzano Emilia (BO), Italy) for their advice on cell culture protocols.

\section{References}

Airas L, Hellman J, Salmi M, Bono P, Puurunen T, Smith DJ \& Jalkanen S 1995 CD73 is involved in lymphocyte binding to the endothelium: characterization of lymphocyte-vascular adhesion protein 2 identifies it as CD73. Journal of Experimental Medicine 182 1603-1608. (doi:10. 1084/jem.182.5.1603)

Barnes D, McKeehan WL \& Sato GH 1987 Cellular endocrinology: integrated physiology in vitro. In Vitro Cellular \& Developmental Biology 23 659-662. (doi:10.1007/BF02620978)

Bellows CG, Pei W, Jia Y \& Heersche JNM 2003 Proliferation, differentiation and self-renewal of osteoprogenitors in vertebral cell populations from aged and young female rats. Mechanisms of Ageing and Development 124 747-757. (doi:10.1016/S0047-6374(03)00088-5) 
Beltrami AP, Barlucchi L, Torella D, Baker M, Limana F, Chimenti S, Kasahara H, Rota M, Musso E, Urbanek K et al. 2003 Adult cardiac stem cells are multipotent and support myocardial regeneration. Cell $\mathbf{1 1 4}$ 763-776. (doi:10.1016/S0092-8674(03)00687-1)

Berg LC, Koch TG, Heerkens T, Besonov K, Thomsen PD \& Betts DH 2009 Chondrogenic potential of mesenchymal stromal cells derived from equine bone marrow and umbilical cord blood. Veterinary and Comparative Orthopaedics and Traumatology 22 363-370.

Bergman RJ, Gazit D, Kahn AJ, Gruber H, McDougall S \& Hahn TJ 1996 Age related changes in osteogenic stem cells in mice. Journal of Bone and Mineral Research 11 568-577. (doi:10.1002/jbmr. 5650110504)

Chen J, Sotome S, Wang J, Orii H, Uemura T \& Shinomiya K 2005 Correlation of in vivo bone formation capability and in vitro differentiation of human bone marrow stromal cells. Journal of Medical and Dental Sciences 52 27-34.

Colleoni S, Bottani E, Tessaro I, Mari M, Merlo B, Romagnoli N, Spadari A, Galli C \& Lazzari G 2009 Isolation, growth and differentiation of equine mesenchymal stem cells: effect of donor, source, amount of tissue and supplementation with basic fibroblast growth factor. Veterinary Research Communications 33 811-821. (doi:10.1007/s11259-0099229-0)

Cremonesi F, Violini S, Lange Consiglio A, Ramelli P, Ranzenigo G \& Mariani P 2008 Isolation, in vitro culture and characterization of foal umbilical cord stem cells at birth. Veterinary Research Communications 32 S139-S142. (doi:10.1007/s11259-008-9116-0)

De Coppi P, Bartsch G, Siddiqui MM, Xu T, Santos CC, Perin L, Mostoslavsky G, Serre AC, Snyder EY, Yoo JJ et al. 2007 Isolation of amniotic stem cell lines with potential for therapy. Nature Biotechnology 25 100-106. (doi:10.1038/nbt1274)

D'Ippolito G, Schiller P, Ricordi C, Roos B \& Howard G 1999 Age-related osteogenic potential of mesenchymal stromal stem cells from human vertebral bone marrow. Journal of Bone and Mineral Research 14 1115-1122. (doi:10.1359/jbmr.1999.14.7.1115)

Dominici M, Le Blanc K, Mueller I, Slaper-Cortenbach I, Marini F, Krause D, Deans R, Keating A, Prockop D \& Horwitz E 2006 Minimal criteria for defining multipotent mesenchymal stromal cells. The International Society for Cellular Therapy position statement. Cytotherapy 8 315-317. (doi:10.1080/14653240600855905)

Eloit M 1999 Risks of virus transmission associated with animal sera or substitutes and methods of control. Developments in Biological Standardization 99 9-16.

Erdo F, Buhrle C, Blunk J, Hoehn M, Xia Y, Flieschmann B, Focking M, Kustermann E, Kolossov E, Heschler J et al. 2003 Host-dependent tumorogenesis of embryonic stem cell transplantation in experimental stroke. Journal of Cerebral Blood Flow and Metabolism 23 780-785. (doi:10.1097/01.WCB.0000071886.63724.FB)

Erices A, Conget P \& Minguell JJ 2000 Mesenchymal progenitor cells in human umbilical cord blood. British Journal of Haematology 109 235-242. (doi:10.1046/j.1365-2141.2000.01986.x)

Gosden CM 1983 Amniotic fluid cell types and culture. British Medical Bulletin 39 348-354.

Guest DJ, Smith MRW \& Allen WR 2010 Equine embryonic stem-like cells and mesenchymal stromal cells have different survival rates and migration patterns following their injection into damaged superficial digital flexor tendon. Equine Veterinary Journal 42 636-642. (doi:10.1111/j.2042-3306.2010.00112.x)

Hackett CH \& Fortier LA 2011 Embryonic stem cells and iPS cells: sources and characteristics. Veterinary Clinics of North America Equine Practice 27 233-242. (doi:10.1016/j.cveq.2011.04.003)

Horwitz EM, Prockop DJ, Fitzpatrick LA, Koo WW, Gordon PL, Neel M, Sussman M, Orchard P, Marx JC, Pyeritz RE \& Brenner MK 1999 Transplantability and therapeutic effects of bone marrow-derived mesenchymal cells in children with osteogenesis imperfecta. Nature Medicine 5 309-313.

Hoynowski SM, Fry MM, Gardner BM, Leming MT, Tucker JR, Black L, Sand T \& Mitchell KE 2007 Characterization and differentiation of equine umbilical cord-derived matrix cells. Biochemical and Biophysical Research Communications 362 347-353. (doi:10.1016/j.bbrc. 2007.07.182)
In't Anker PS, Scherjon SA, Kleijburg van der Keur C, Noort WA, Claas FH, Willemze R, Fibbe WE \& Kanhai HH 2003 Amniotic fluid as a novel source of mesenchymal stem cells for therapeutic transplantation. Blood 102 1548-1549. (doi:10.1182/blood-2003-04-1291)

Karahuseyinoglu S, H Cinar O, Kilic E, Kara F, Akay GG, Demiralp DO, Tukun A, Uckan D \& Can A 2007 Biology of stem cells in human umbilical cord stroma: in situ and in vitro surveys. Stem Cells $\mathbf{2 5}$ 319-331.

Kaviani A, Perry TE, Dzakovic A, Jennings RW, Ziegler MM \& Fauza DO 2001 The amniotic fluid as a source of cells for fetal tissue engineering. Journal of Pediatric Surgery 36 1662-1665. (doi:10.1053/jpsu.2001. 27945)

Kern S, Eichler H, Stoeve J, Kluter H \& Bieback K 2006 Comparative analysis of mesenchymal stem cells from bone marrow, umbilical cord blood, or adipose tissue. Stem Cells 24 1294-1301. (doi:10.1634/ stemcells.2005-0342)

Kobayashi K, Kubota T \& Aso T 1998 Study on myofibroblast differentiation in the stromal cells of Wharton's jelly: expression and localization of alpha-smooth muscle actin. Early Human Development 51 223-233. (doi:10.1016/S0378-3782(97)00123-0)

Koch TG, Heerkens T, Thomsen PD \& Betts DH 2007 Isolation of mesenchymal stem cells from equine umbilical cord blood. BMC Biotechnology 7 26-34. (doi:10.1186/1472-6750-7-26)

Koch TG, Thomsen PD \& Betts DH 2009 Improved isolation protocol for equine cord blood derived mesenchymal stromal cells. Cytotherapy $\mathbf{1 1}$ 443-447. (doi:10.1080/14653240902887259)

Koso H, Satoh S \& Watanabe S 2007 c-kit marks late retinal progenitor cells and regulates their differentiation in developing mouse retina. Developmental Biology 301 141-154. (doi:10.1016/j.ydbio.2006.09.027)

Kretlow JD, Jin Y, Liu W, Zhang WJ, Hong T, Zhou G, Baggett LS, Mikos AG \& Cao Y 2008 Donor age and cell passage affects differentiation potential of murine bone marrow-derived stem cells. BMC Cell Biology 960. (doi:10.1186/1471-2121-9-60)

Li X, Zhou SG, Imreh MP, Ahrlund-Richter L \& Allen WR 2006 Horse embryonic stem cell like cell lines from the proliferation of inner cell mass cells. Stem Cells and Development 15 523-531.

Liao J, Cui C, Chen S, Ren J, Chen J, Gao Y, Li H, Jia N, Cheng L, Xiao H et al. 2009 Generation of induced pluripotent stem cell lines from adult rat cells. Cell Stem Cell 4 11-15. (doi:10.1016/j.stem.2008.11.013)

Liu H, Zhu F, Yong J, Zhang P, Hou P, Li H, Jiang W, Cai J, Liu M, Cui K et al. 2008 Generation of induced pluripotent stem cells from adult rhesus monkey fibroblasts. Cell Stem Cell 3 587-590. (doi:10.1016/j.stem. 2008.10.014)

Lovati AB, Corradetti B, Lange Consiglio A, Recordati C, Bonacina E, Bizzaro D \& Cremonesi F 2011 Comparison of equine bone marrow-, umbilical cord matrix and amniotic fluid-derived progenitor cells. Veterinary Research Communications 35 103-121. (doi:10.1007/ s11259-010-9457-3)

Lu LL, Liu YJ, Yang SG, Zhao QJ, Wang X, Gong W, Han ZB, Xu ZS, Lu YX, Liu D et al. 2006 Isolation and characterization of human umbilical cord mesenchymal stem cells with hematopoiesis-supportive function and other potentials. Haematologica 91 1017-1026.

Majors AK, Boehm CA, Nitto H, Midura RJ \& Muschler GF 1997 Characterization of human bone marrow stromal cells with respect to osteoblastic differentiation. Journal of Orthopaedic Research $\mathbf{1 5}$ 546-557. (doi:10.1002/jor.1100150410)

Mareschi K, Ferrero I, Rustichelli D, Aschero S, Gammaitoni L, Aglietta M, Madon E \& Fagioli F 2006 Expansion of mesenchymal stem cells isolated from pediatric and adult donor bone marrow. Journal of Cellular Biochemistry 97 744-754. (doi:10.1002/jcb.20681)

Martin GM, Sprague CA \& Epstein CJ 1970 Replicative lifespan of cultivated human cells. Effects of donor's age, tissue, and genotype. Laboratory Investigation 23 86-92.

de Mattos Carvalho A, Alves AL, Golim MA, Moroz A, Hussni CA, de Oliveira PG \& Deffune E 2009 Isolation and immunophenotypic characterization of mesenchymal stem cells derived from equine species adipose tissue. Veterinary Immunology and Immunopathology 132 303-306. (doi:10.1016/j.vetimm.2009.06.014)

Mendes SC, Tibbe JM, Veenhof M, Bakker K, Both S, Platenburg PP, Oner FC, de Bruijn JD \& van Blitterswijk CA 2002 Bone 
tissue-engineered implants using human bone marrow stromal cells: effect of culture conditions and donor age. Tissue Engineering 8 911-920. (doi:10.1089/107632702320934010)

Mizuno H \& Hyakusoku H 2003 Mesengenic potential and future clinical perspective of human processed lipoaspirate cells. Journal of Nippon Medical School 70 300-306. (doi:10.1272/jnms.70.300)

Nagy K, Sung HK, Zhang P, Laflamme S, Vincent P, Agha-Mohammadi S, Woltjen K, Monetti C, Michael IP, Smith LC et al. 2011 Induced pluripotent stem cell lines derived from equine fibroblasts. Stem Cell Reviews 7 693-702. (doi:10.1007/s12015-011-9239-5)

Naito Y \& Lowenstein JM $19815^{\prime}$-Nucleotidase from rat heart. Biochemistry 20 5188-5194. (doi:10.1021/bi00521a014)

Nakamura Y, Muguruma Y, Yahata T, Miyatake H, Sakai D, Mochida J, Hotta T \& Ando K 2006 Expression of CD90 on keratinocyte stem/progenitor cells. British Journal of Dermatology 154 1062-1070. (doi:10.1111/j.1365-2133.2006.07209.x)

Nanaev AK, Kohnen G, Milovanov AP, Domogatsky SP \& Kaufmann P 1997 Stromal differentiation and architecture of the human umbilical cord. Placenta 18 53-64. (doi:10.1016/S0143-4004(97)90071-0)

Nelson TJ, Faustino RS, Chiriac A, Crespo-Diaz R, Behfar A \& Terzic A 2008 CXCR4 +/FLK-1 + biomarkers select a cardiopoietic lineage from embryonic stem cells. Stem Cells 26 1464-1473. (doi:10.1634/ stemcells.2007-0808)

Nelson TJ, Martinez-Fernandez A, Yamada S, Ikeda Y, Perez-Terzic C \& Terzic A 2010 Induced pluripotent stem cells: advantages to applications. Stem Cells and Cloning: Advances and Applications 3 29-37. (doi:10.2147/SCCAA.S4954)

Park IH, Zhao R, West JA, Yabuuchi A, Huo H, Ince TA, Lerou PH, Lensch MW \& Daley GQ 2008 Reprogramming of human somatic cells to pluripotency with defined factors. Nature 451 141-146. (doi:10.1038/ nature06534)

Park SB, Seo MS, Kang JG, Chae JS \& Kang KS 2011 Isolation and characterization of equine amniotic fluid-derived multipotent stem cells. Cytotherapy 13 341-349. (doi:10.3109/14653249.2010. 520312)

Pascucci L, Curina G, Mercati F, Marini C, Dall'Aglio C, Paternesi B \& Ceccarelli P 2011 Flow cytometric characterization of culture expanded multipotent mesenchymal stromal cells (MSCs) from horse adipose tissue: towards the definition of minimal stemness criteria. Veterinary Immunology and Immunopathology 144 499-1506.

Passeri S, Nocchi F, Lamanna R, Lapi S, Miragliotta V, Giannessi E, Abramo F, Stornelli MR, Matarazzo M, Plenteda D et al. 2009 Isolation and expansion of equine umbilical cord-derived matrix cells (EUCMCs). Cell Biology International 33 100-105. (doi:10.1016/j.cellbi.2008. 10.012)

Perin L, Giuliani S, Jin D, Sedrakyan S, Carraro G, Habibian R, Warburton D, Atala A \& De Filippo RE 2007 Renal differentiation of amniotic fluid stem cells. Cell Proliferation 40 936-948. (doi:10.1111/j. 1365-2184.2007.00478.x)

Pesce M \& Scholer HR 2001 Oct-4: gatekeeper in the beginning of mammalian development. Stem Cells 19 271-278. (doi:10.1634/ stemcells.19-4-271)

Prusa AR, Marton E, Rosner M, Bernaschek G \& Hengstschlager M 2004 Oct-4-expressing cells in human amniotic fluid: a new source for stem cell research? Human Reproduction 18 1489-1493. (doi:10.1093/ humrep/deg279)

Reubinoff BE, Pera MF, Fong CY, Trounson A \& Bongso A 2000 Embryonic stem cell lines from human blastocytes: somatic differentiation in vitro. Nature Biotechnology 18 399-404. (doi:10.1038/74447)

Romanov YA, Svintsitskaya VA \& Smirnov VN 2003 Searching for alternative sources of postnatal human mesenchymal stem cells: candidate MSC like cells from umbilical cord. Stem Cells 21 105-110. (doi:10.1634/stemcells.21-1-105)

Sackstein R, Merzaban JS, Cain DW, Dagia NM, Spencer JA, Lin CP \& Wohlgemuth R 2008 Ex vivo glycan engineering of CD44 programs human multipotent mesenchymal stromal cell trafficking to bone. Nature Medicine 14 181-187. (doi:10.1038/nm1703)

Saito S, Ugai H, Sawaid K, Yamamoto Y, Minamihashi A, Kurosaka K, Kobayashi Y, Murata T, Obata Y \& Yokoyama K 2002 Isolation of embryonic stem-like cells from equine blastocysts and their differentiation in vitro. FEBS Letters 531 389-396.
Sarugaser R, Lickorish D, Baksh D, Hosseini MM \& Davies JE 2005 Human umbilical cord perivascular (HUCPV) cells: a source of mesenchymal progenitors. Stem Cells 23 220-229. (doi:10.1634/stemcells.2004-0166)

Schallmoser K, Bartmann C, Rohde E, Reinisch A, Kashofer K, Stadelmeyer E, Drexler C, Lanzer G, Linkesch W \& Strunk D 2007 Human platelet lysate can replace fetal bovine serum for clinical-scale expansion of functional mesenchymal stromal cells. Transfusion 47 1436-1446. (doi:10.1111/j.1537-2995.2007.01220.x)

Schneider EL \& Mitsui Y 1976 The relationship between in vitro cellular aging and in vivo human age. PNAS 73 584-588. (doi:10.1073/pnas.73. 10.3584)

Secco M, Zucconi E, Vieira NM, Fogac LLQ, Cerqueira A, Carvalho MDF, Jazeidje T, Okamoto OK, Muotri AR \& Zatz M 2008 Multipotent stem cells from umbilical cord: cord is richer than blood!. Stem Cells $\mathbf{2 6}$ 146-150. (doi:10.1634/stemcells.2007-0381)

Seo MJ, Suh SY, Bae YC \& Jung JS 2005 Differentiation of human adipose stromal cells into hepatic lineage in vitro and in vivo. Biochemical and Biophysical Research Communications 328 258-264. (doi:10.1016/j. bbrc.2004.12.158)

Sethe S, Scutt A \& Stolzing A 2006 Aging of mesenchymal stem cells. Ageing Research Reviews 5 91-116. (doi:10.1016/j.arr.2005.10.001)

Stenderup K, Justesen J, Eriksen EF, Rattan SI \& Kassem M 2001 Number and proliferative capacity of osteogenic stem cells are maintained during aging and in patients with osteoporosis. Journal of Bone and Mineral Research 16 1120-1129. (doi:10.1359/jbmr.2001.16.6.1120)

Stenderup K, Justesen J, Clausen C \& Kassem IM 2003 Aging is associated with decreased maximal life span and accelerated senescence of bone marrow stromal cells. Bone 33 919-926. (doi:10.1016/j.bone.2003.07. 005)

Stocum DL 2001 Stem cell in regenerative biology and medicine. Wound Repair and Regeneration 9 429-442. (doi:10.1046/j.1524-475x.2001. 00429.x)

Stolzing A, Jones E, McGonagle D \& Scutt A 2008 Age-related changes in human bone marrow derived mesenchymal stem cells: consequences for cell therapies. Mechanisms of Ageing and Development 129 163-173. (doi:10.1016/j.mad.2007.12.002)

Strem BM, Hicok KC, Zhu M, Wulur I, Zeni A, Schreiber RE, Fraser JK \& Hedrick MH 2005 Multipotential differentiation of adipose tissuederived stem cells. Keio Journal of Medicine 54 132-141. (doi:10. 2302/kjm.54.132)

Takahashi K \& Yamanaka S 2006 Induction of pluripotent stem cells from mouse embryonic and adult fibroblast cultures by defined factors. Cel/ 26 663-676. (doi:10.1016/j.cell.2006.07.024)

Takechi K, Kuwabara Y \& Mizuno M 1993 Ultrastructural and immunohistochemical studies of Wharton's jelly umbilical cord cells. Placenta $\mathbf{1 4}$ 235-245. (doi:10.1016/S0143-4004(05)80264-4)

Thomson JA, Istkovitz Eldor J, Shapiro SS, Waknitz MA, Swiergiel JJ \& Marshall VS 1998 Embryonic stem cell lines derived from human blastocysts. Science 282 1145-1147. (doi:10.1126/science.282.5391. 1145)

Tsai MS, Lee JL, Chang YJ \& Hwang SM 2004 Isolation of human multipotent mesenchymal stem cells from second-trimester amniotic fluid using a novel two-stage culture protocol. Human Reproduction 19 1450-1456. (doi:10.1093/humrep/deh279)

Vaala WE 2006 Perinatology. In The Equine Manual, 2nd edn, pp 803-804. Eds AJ Higgins \& JR Snyder. Elsevier Press.

van der Valk J, Mellor D, Brands R, Fischer R, Gruber F, Gstraunthaler G, Hellebrekers L, Hyllner J, Jonker FH, Prieto P et al. 2004 The humane collection of fetal bovine serum and possibilities for serum-free cell and tissue culture. Toxicology In Vitro 18 1-12. (doi:10.1016/j.tiv.2003.08. 009)

Vidal MA, Kilroy GE, Lopez ME, Johnson JR, Moore RM \& Gimble JM 2007 Characterization of equine adipose tissue-derived stromal cells: adipogenic and osteogenic capacity and comparison with bone marrow-derived mesenchymal stromal cells. Veterinary Surgery $\mathbf{3 6}$ 613-622. (doi:10.1111/j.1532-950X.2007.00313.x)

Wang HS, Hung SC, Peng ST, Huang CC, Wei HM, Guo YJ, Fu YS, Lai MC \& Chen CC 2004 Mesenchymal stem cells in the Wharton's jelly of the human umbilical cord. Stem Cells 22 1330-1337. (doi:10.1634/ stemcells.2004-0013)

Weiss ML, Medicetty S, Bledsoe AR, Rachakatla RS, Choi M, Merchav S, Luo Y, Rao MS, Velagaleti G \& Troyer D 2006 Human umbilical cord 
matrix stem cells: preliminary characterization and effect of transplantation in a rodent model of Parkinson's disease. Stem Cells $\mathbf{2 4}$ 781-792. (doi:10.1634/stemcells.2005-0330)

You Q, Cai L, Zheng J, Tong X, Zhang D \& Zhang Y 2008 Isolation of human mesenchymal stem cells from third-trimester amniotic fluid. International Journal of Gynaecology and Obstetrics 103 149-152. (doi:10.1016/j. ijgo.2008.06.012)

Zhang H, Fazel S, Tian H, Mickle DAG, Weisel RD, Fujii T \& Li RK 2005 Increasing donor age adversely impacts beneficial effects of bone marrow but not smooth muscle myocardial cell therapy. American Journal of Physiology. Heart and Circulatory Physiology 289 H2089-H2096. (doi:10.1152/ajpheart.00019.2005)
Zheng H, Martin JA, Duwayri Y, Falcon G \& Buckwalter JA 2007 Impact of aging on rat bone marrow-derived stem cell chondrogenesis. Journals of Gerontology. Series A, Biological Sciences and Medical Sciences 62 136-148. (doi:10.1093/gerona/62.2.136)

Received 28 September 2010

First decision 12 November 2010

Revised manuscript received 2 December 2011

Accepted 20 January 2012 